\title{
DIFFERENCES BETWEEN PHENOTYPIC AND GENOTYPE CHARACTERIZATION OF S. AUREUS ISOLATED FROM BOVINE MASTITIS IN EGYPT
}

\author{
ALAA EL-DIN MOUSTAFA ${ }^{1}$; AHMED HAMMAD ${ }^{2}$ AND MAI DAWOUD ${ }^{1}$ \\ ${ }^{1}$ Department of Bacteriology, Mycology and Immunology, Faculty of Veterinary \\ Medicine, University of Sadat City, Egypt. \\ ${ }^{2}$ Department of Food Hygiene and Control, Faculty of Veterinary Medicine, \\ University of Sadat City, Egypt.
}

Received: 31 December 2020; Accepted: 30 April 2021

\begin{abstract}
S. aureus is one of the most important causes of nosocomial infections, main contagious pathogens that can play a vital and important role in bovine mastitis in veterinary medicine causing high worldwide economic losses, where the primary reservoir harboring the pathogens is cow, and recently recorded as zoonotic microbe which able to transmitted from human to animal and vice versa, identification of staphylococcus species mainly $S$. aureus become more quickly and accurate with molecular technique as phenotypic technique due to multidrug resistance developed some mutation and production of biofilm which interference phenotypic identification, as nис gene, and coa gene become the golden standard technique for identification $S$. aureus and the study concerned the differentiation between phenotypic and genotypic characterization of isolates collected from milk samples of bovine mastitis, as directed 157 phenotypic staphylococcus isolates on MSA media to biochemical phenotypic tests as 81/157 (51.6\%) isolates of them were phenotypic S. aureus, and by molecular technique, 16S universal primer detected 141/157 (89.8\%) were confirmed staphylococcus about 130/141(92.2\%) were CoPS by coa gene detection, and 111/141 (78.7\%) were typical $S$. aureus detected by nис gene, as most of them produced biofilm that detected by ica gene in $81 / 141(57.4 \%)$ was the main cause of interrupting the phenotypic characterization by biochemical tests.
\end{abstract}

Keywords: bovine mastitis, coagulase positive staphylococcus (CoPS), coa gene, ica gene (biofilm formation gene), nuc gene, S. aureus.

\section{INTRODUCTION}

Bovine mastitis is multifaceted etiopathology, as including three main factors: 1.exposure to microorganisms, 2.host defense mechanisms, and 3.environmental

Corresponding author: Mai Dawoud

E-mail address: mai_dawoud30@yahoo.com

Present address: Department of Bacteriology, Mycology and Immunology, Faculty of Veterinary Medicine, conditions (Zadoks et al., 2001).

Among all these factors that cause bovine mastitis, $S$. aureus are the main pathogens that can play a vital and important role in mastitis (Lundberg et al., 2014), also The SCM (sub-clinical mastitis) is a multietiologic disease, many microorganisms is implicated as causes. S. aureus and Streptococcus agalactiae as dominant Contagious pathogens of SCM, are transmitted from animal to animal where the 
primary reservoir harboring the pathogens is the cow (Shawky et al., 2013 and Youssif et al., 2020).

S. aureus secretes two clotting factors, von Willebrand factor binding protein and coagulase (coa) protein. The coa protein is an important phenotypic determinant and virulence factor of $S$. aureus. The ability of its coa to clot plasma is a defining property of $S$. aureus and distinguished the species from other coa-negative staphylococci (Gharib et al., 2013; Abbas et al., 2014 and Foster et al., 2015). The tube coagulase test with diluted rabbit plasma is the accepted confirmation of an identification of Staphylococcus aureus, but either a tube test with human plasma broth or some variant of the slide clumping factor (bound coagulase) test is more often used at the bench. With most human strains there is no difficulty, but it has been suggested that strains of $\mathrm{S}$ aureus, which are resistant to methicillin, are deficient in clumping factor and even in Protein A. Lally and Woolfrey, found that some strains of $S$. aureus resistant to methicillin may be particularly deficient, and similar findings were reported at a workshop on the problems caused by some strains resistant to this drug. Other characters such as DNase production, phosphatase, and ability to acidify mannitol salt agar have been used with varying efficacy to confirm or suggest an identification of a strain as $\mathrm{S}$ aureus (Saraiva et al., 2018).

The coa gene of $S$. aureus isolated as considered the most simple and accurate tool for molecular typing. that also reported that this technique could be used in epidemiological detection of $S$. aureus isolates from cattle mastitis as had a high reproducibility and good discriminatory power, it is the easiest with which to analyze coa gene polymorphism among a large number of bacterial isolates, and it generates multiple distinct polymorphism patterns ( $\mathrm{Da}$ Silva and Da Silva, 2005).

Phenotypic characterization by conventional bacteriology of Staphylococcus aureus is no longer beneficial in controlling mastitis caused by this organism since inter-strain variations exist in terms of virulence potential (Pilla et al., 2013). This returned to Most of the $S$. aureus strains formed the biofilm in an ica-dependent mechanism (Kostaki et al., 2012; Mah 2012; Bridier et al., 2015 and Avila-Novoa et al., 2018), S. aureus abled to adhere to the surface of indwelling medical devices and develop biofilm, a multilayered structure comprising of bacterial communities embedded within the extra- cellular hydrated polymeric matrix (Paharik and Horswill, 2016).

Recently, PCR has become a very popular molecular technique, especially for the detection and identification of bacteria in mastitic milk by targeting their specific genes in the DNAs, Molecular diagnostic methods like DNA-based mastitis diagnostic system have already been introduced for routine use in the dairy herds (Koskinen et al., 2009; Taponen et al., 2009; Elsayed et al., 2015 and Hoque et al, 2018).

\section{MATERIALS AND METHODS}

\section{Collected samples tools:}

A total of 400 milk samples from clinical mastitis and apparent healthy (sub-clinical) cows, were collected from different localities and dairy cattle farms in Monofyia Governorate. The samples were collected under complete aseptic condition (5 $\mathrm{ml}$ of milk collected in sterile falcon tubes) collected from clinically diseased cows (characterized by abnormal milk secretion containing clots, flocks, blood, some with swelling / hardness of the mammary gland and others with systematic disturbance as fever and loss of appetite) and from apparent healthy cows with no signs on udder tissue or fresh raw milk with some exception for some calves whose refuse to breastfeed without a satisfactory reason and persistent diarrhea in some suckling calves. The collected samples were aseptically transferred to the laboratory in an insulated ice box to be examined immediately with a minimum delay to detect the presence of 
staphylococcus species. Using standard techniques recommended by (Collee et al., 1989) and National Mastitis Council of United States (Anonymous, 1990).

\section{Bacteriological examination:}

Pre enrichment milk sample (APHA., 1992):

Inoculation $1 \mathrm{ml}$ of sample in $5 \mathrm{ml}$ of sterile BHI broth (sterilized by autoclaving at $121^{\circ} \mathrm{C}$ for 15 minutes) incubated at $37^{\circ} \mathrm{C}$ for 24 hours.

Mannitol salt agar medium (MSA) (APHA., 1966):

A selective medium for the isolation of presumptive pathogenic staphylococci. And Presumptive coagulase-positive staphylococci produce colonies surrounded by bright yellow zones whilst nonpathogenic staphylococci produce colonies with reddish purple zones. Suspend $111 \mathrm{~g}$ in 1 liter of distilled water and bring to the boil to dissolve completely. Sterilized by autoclaving at $121^{\circ} \mathrm{C}$ for 15 minutes. Poured in sterile petri-dishes and sample material streaked across the plate using sterilized loop and Incubate at $37^{\circ} \mathrm{C}$ for 24 hours. Examine after 24 hours for yellow colonies surrounded by bright yellow zones (positive result).

\section{Microscopic appearance:}

Gram Staining (Cruickshank et al., 1975): Films were prepared from pure culture of the isolated organisms and stained with Gram's stain and examined microscopically. $S$. aureus are Gram positive cocci arranged in clusters.

Biochemical identification of Staphylococci according to (McFadden, 1980; Carter and Cole, 1990 and Quinn et al., 1994):

The following biochemical tests were adopted for identification of isolates:

\section{A. Oxidase test:}

Applied by using Oxidase detection strips \{CODE: MB0266, (Thermo Sci.)®\} Touch the colony to be tested with the Oxidase Detection Strip and observe for up to 5 seconds. A deep blue/violet color indicates a positive reaction.

\section{B. Catalase test:}

Loop full of suspected pure culture growth from nutrient agar slant was mixed with 3 drops of $30 \%$ of hydrogen peroxides on a glass slide. The production of gas bubbles immediately constitutes a positive reaction.

\section{Tube Coagulase test:}

Suspect staphylococci colonies were transferred from solid media into small tubes containing 0.2-0.3 ml nutrient broth and emulsified thoroughly. Incubated at $37^{\circ} \mathrm{c}$ for 24 hour. Then $0.5 \mathrm{ml}$ reconstituted coagulates human plasma with EDTA was added to nutrient broth and mixed thoroughly. The tubes were incubated at $37^{\circ} \mathrm{c}$ and examined periodically over $6 \mathrm{hrs}$. For clot formation. (Koneman et al., 1997). Only firm and complete clot that stay in place when tubes was titled or inverted was considered positive. Partial clotting, formerly $2+$ and $3+$ coagulase reaction must tested further.

\section{Gelatin hydrolysis test (McDade et al., 1958):}

It distinguishes the gelatinize-positive, pathogenic $S$. aureus from the gelatinizenegative, non-pathogenic $S$. epidermidis. Inoculate a heavy inoculum of test bacteria (18- to 24-hour-old) by stabbing 4-5 times (half inch) on the tube containing nutrient gelatin medium. Incubate the inoculated tube along with an un-inoculated medium at $35^{\circ} \mathrm{C}$, or at the test bacterium's optimal growth temperature, for up to 2 weeks. Remove the tubes daily from the incubator and place in ice bath or refrigerator $\left(4^{\circ} \mathrm{C}\right)$ for 15-30 minutes (until control is gelled) every day to check for gelatin liquefaction. (Gelatin normally liquefies at $28^{\circ} \mathrm{C}$ and above, so to confirm that liquefaction was due to gelatinize activity, the tubes are immersed in an ice bath or kept in refrigerator at $4^{\circ} \mathrm{C}$ ). Tilt the tubes to observe if gelatin has been hydrolyzed. Partial or total liquefaction of the inoculated tube even after exposure to cold temperature of ice 
bath or refrigerator $\left(4^{\circ} \mathrm{C}\right)$ positive $S$. aureus, Complete solidification of the inoculated tube even after exposure to cold temperature of ice bath or refrigerator $\left(4^{\circ} \mathrm{C}\right)$.

Trehalose fermentation test (Oxoid, 1996) $1 \%$ peptone water containing $1 \%$ trehalose (sigma $\left.{ }^{\circledR}\right)$ sterilized tubes by autoclaving at $121^{\circ} \mathrm{C}$ for 15 minutes. And inoculated by pure colonies and incubated at $37^{\circ} \mathrm{c}$ for 24 hrs. then adding phenol red as indicator for detection a positive result yellow color due to fermentation of sugar and production acid due to change $\mathrm{pH}$ to acidic.

\section{PCR technique:}

DNA Purification protocol
Preparing fresh BHI broth from isolates and incubated at $37^{\circ} \mathrm{C}$ for $18 \mathrm{hrs}$. using igenomic BYF DNA Extraction Mini Kit) (iNtRON Biotechnology) ®for DNA purification.

\section{PCR techniques: \\ DNA amplification}

PCR reaction were performed, each reaction mixture contained $5 \mu$ l of prepared template DNA, $0.5 \mu \mathrm{l}$ of each primer, $12.5 \mu \mathrm{l}$ of $2 \times$ EasyTaq $^{\circledR}$ PCR SuperMix (transbionovo) (B) and the final volume was adjusted to $25 \mathrm{ul}$ with distilled water. PCR was performed in rotor gene thermo cycler with the following table data.

Table 1: Primer Nucleotides sequences, and PCR was performed in rotor gene thermo cycler with the following steps:

\begin{tabular}{|c|c|c|c|}
\hline Gene & $\begin{array}{l}\text { Product } \\
\text { size }\end{array}$ & $\begin{array}{l}\text { Primer Nucleotides sequence } \\
\left(5^{\prime}-3^{\prime}\right)\end{array}$ & Reference \\
\hline $\begin{array}{c}16 \mathrm{~S} \\
\text { rRNA }\end{array}$ & $756 \mathrm{bp}$ & $\begin{array}{l}\text { 5-AAC TCT GTT ATT AGG GAA GAA CA-3` } \\
5 \text {-CCA CCT TCC TCC GGT TTG TCA CC-3`}\end{array}$ & $\begin{array}{c}\text { Zhang et al., } \\
2004\end{array}$ \\
\hline \multicolumn{4}{|c|}{$\begin{array}{l}94^{\circ} \mathrm{C} \text { for } 5 \text { min followed by } 10 \text { cycles of } 94^{\circ} \mathrm{C} \text { for } 45 \text { seconds, } 55^{\circ} \mathrm{C} \text { for } 45 \text { seconds, and } 72^{\circ} \mathrm{C} \\
\text { for } 1.5 \text { min and another } 25 \text { cycles of } 94^{\circ} \mathrm{C} \text { for } 45 \text { seconds, } 50^{\circ} \mathrm{C} \text { for } 45 \text { seconds, and } 72^{\circ} \mathrm{C} \text { for } \\
1.5 \mathrm{~min} \text {, ending with a final extension step at } 72^{\circ} \mathrm{C} \text { for } 10 \mathrm{~min}\end{array}$} \\
\hline Nuc & 279 bp & $\begin{array}{c}\text { GCG ATT GAT GGT GAT ACG GTT } \\
\text { AGC CAA GCC TTG ACG AAC TAA AGC }\end{array}$ & Shortle, 1983 \\
\hline Ica gene & $483 \mathrm{bp}$ & $\begin{array}{c}\text { GAA CCG CTT GCC ATG TGT TG } \\
\text { GCT TGA CCA TGT TGC GTA ACC }\end{array}$ & $\begin{array}{l}\text { Namvar et al., } \\
2013\end{array}$ \\
\hline \multicolumn{4}{|c|}{$\begin{array}{l}\text { an initial denaturation step at } 95^{\circ} \mathrm{C} \text { for } 2 \text { min followed by } 30 \text { cycles at } 94^{\circ} \mathrm{C} \text { for } 30 \mathrm{~s}, 55^{\circ} \mathrm{C} \text { for } \\
30 \mathrm{~s} \text { and } 72^{\circ} \mathrm{C} \text { for } 60 \mathrm{~s} \text { and a final extension step at } 72^{\circ} \mathrm{C} \text { for } 7 \mathrm{~min}\end{array}$} \\
\hline Coa & Polymorphism & $\begin{array}{l}\text { CGA GAC CAA GAT TCA ACA AG } \\
\text { AAA GAA AAC CAC TCA CAT CA }\end{array}$ & Guler et al., 2005 \\
\hline
\end{tabular}

Separation of PCR amplicons by Gel Electrophoresis: After the amplification was completed the amplified products was analyzed on agarose gel (consisted of $1.5 \%$ agarose in $1 \times$ Tris-Acetate EDTA (TAE) buffer or TBE and $1.5 \mu \mathrm{l}$ of ethidium bromide. The samples were electrophoresed at 80 volts for one hour, shown under ultra violet trans-illuminator and photographed.

\section{RESULTS AND DISCUSION}

The microbial examination of A total 400 mastitis milk samples on MSA media as $271 / 400(67.75 \%)$ were positive growth on MSA medium out of them 240 sample represented by yellow to orange colonies surround by yellow halo on the other hand 31 isolates appear as pink colony without changing surround medium acc. to JP., 2017; USP, 1995/2018 and EP, 2020. 
Table 2: Different colonies represented by mannitol salt ager medium (MSA) for positive staphylococcus spp isolates.

\begin{tabular}{ccc}
\hline Total sample & $\begin{array}{c}\text { yellow colony surround by yellow halo on } \\
\text { MSA medium }\end{array}$ & pink colony on MSA medium \\
\hline $271(100 \%)$ & $240(88.6 \%)$ & $31(11.4 \%)$ \\
\hline Suspected & S. aureus & \\
staphylococcus & S. intermidius, S. xylosus, S. haemolyticus,, & S. epidermidis, S. lugdunensis, \\
spp. Causing & S. saprophyticus., S. schleiferi subsp \\
bovine mastitis & coagulans, S. delphini & S. hyicus \\
\hline
\end{tabular}

Biochemical characters of 157(100\%) suspected staphylococcus isolates (according to Procop et al., 2017) as all negative oxidase test and positive catalase test ,some of them staining by gram's stain showing gram positive cocci arranged in clusters (grapes like appearance). The tube coagulase test preformed as $81 / 157(51.6 \%)$ were positive clot formation that may indicate $S$. aureus, Gelatin liquefaction test represented
81/157 (51.6\%) positive pathogenic $S$. aureus. In addition to perform a terhalose fermentation test 157/157 (100\%) Positive terhalose fermentation may produce by $S$. aureus, $S$. intermidius, $S$. xyloses, $S$. haemolyticus, S. saprophyticus, S.hyicus.

We concluded from this previous result that typical phenotypic $S$. aureus represented by 81/157 (51.6\%).

Table 3: Biochemical test to classification staphylococcus spp isolates.

\begin{tabular}{cccccc}
\hline test & no. of sample & poitive & variable & negative & indication \\
\hline catalase test & 157 & $157(100 \%)$ & 0 & 0 & $\begin{array}{c}\text { All staphylococci species } \\
\text { catalase positive }\end{array}$ \\
\hline $\begin{array}{c}\text { oxidase test } \\
\text { tube coagulase } \\
\text { test }\end{array}$ & 157 & 0 & 0 & $157(100 \%)$ & $\begin{array}{c}\text { All staphylococci species } \\
\text { oxidase negative }\end{array}$ \\
\hline $\begin{array}{c}\text { gelatin } \\
\text { liquefaction } \\
\text { test }\end{array}$ & 157 & $81(51.6 \%)$ & 0 & $76(48.4 \%)$ & 81 (51.6\%) S. aureus \\
\hline $\begin{array}{c}\text { terhalose } \\
\text { fermentation } \\
\text { test }\end{array}$ & $151(51.6 \%)$ & $6(3.8 \%)$ & $70(44.6 \%)$ & $\begin{array}{c}\text { Positive pathogenic } S . \\
\text { aureus }\end{array}$ \\
\hline & $157(95.5 \%)$ & $7(4.5 \%)$ & 0 & $\begin{array}{c}\text { Positive } \text { S. aureus, } S . \\
\text { intermidius, } \text { S. } \text { xylosus, } S . \\
\text { haemolyticus, } S . \\
\text { saprophyticus, } \text { hyicus/ } \\
\text { Negative } \text { S. epidermidis }\end{array}$ \\
\hline
\end{tabular}

Genotypic characterization of randomly selected 157 phenotypic suspected staphylococcus isolates by cPCR technique. 
Table 4: Genotypic classification of 157 phenotypic suspected staphylococcus isolates by different primers used.

\begin{tabular}{clcc}
\hline gene & no. of sample examined & positive & negative \\
\hline $16 S$ & 157 & $141(89.8 \%)$ & $16(10.2 \%)$ \\
\hline$c o a$ & 141 & $130(92.2 \%)$ & $11(7.8 \%)$ \\
\hline nuc & 141 & $111(78.7 \%)$ & $30(21.3 \%)$ \\
\hline$i c a$ & 141 & $81(57.4 \%)$ & $60(42.6 \%)$ \\
\hline
\end{tabular}

$16 S$ universal staphylococcus primer for detection staphylococcus microorganism (756bp). coa gene primer for detection staphylococcus coagulase positive microorganism (polymorphic band).

nuc primer for detection $S$. aureus positive microorganism (279 bp).

ica primer for detection staphylococcus biofilm formation positive (483 bp).

*\% was calculated according to positive isolates (141)

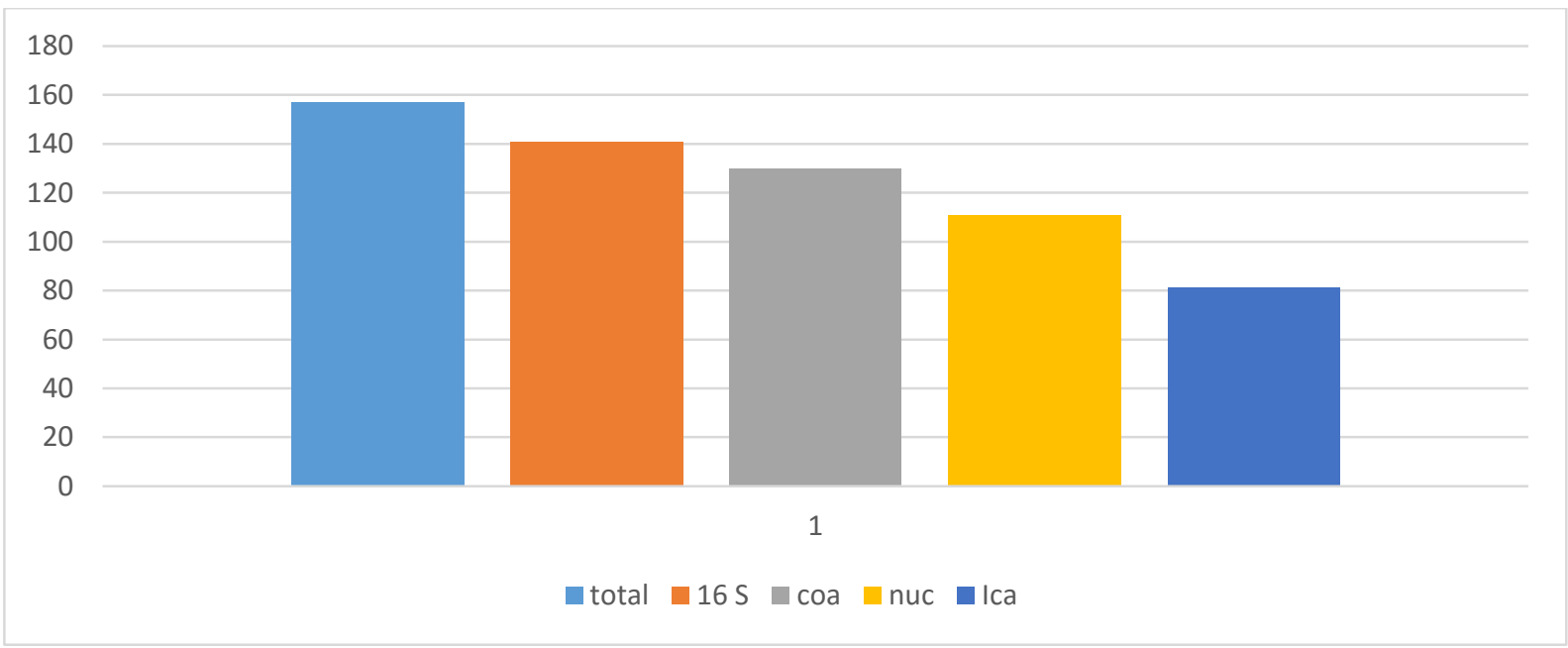

Chart (1): represent genotypic classification of 157 phenotypic suspected staphylococcus isolates by different primers

Genotypic cPCR of randomly selected 157 phenotypic suspected staphylococcus isolates examined by $16 \mathrm{~S}$ universal primer for staphylococcus as 141/157(89.8\%) of phenotypic suspected staphylococci isolates were confirmed as staphylococci, coagulase gene (Coa gene) detected 130/141 (92.2\%) confirmed as coagulase positive staphylococcus isolates, пис gene (specific gene for $S$. aureus) were confirmed 111/141(78.7\%) S. aureus isolates, Also ica gene detected in $81 / 141(57.4 \%)$ isolates have the ability to produce biofilm formation as one of resistant action performed by $S$. aureus to resist antibiotics. 


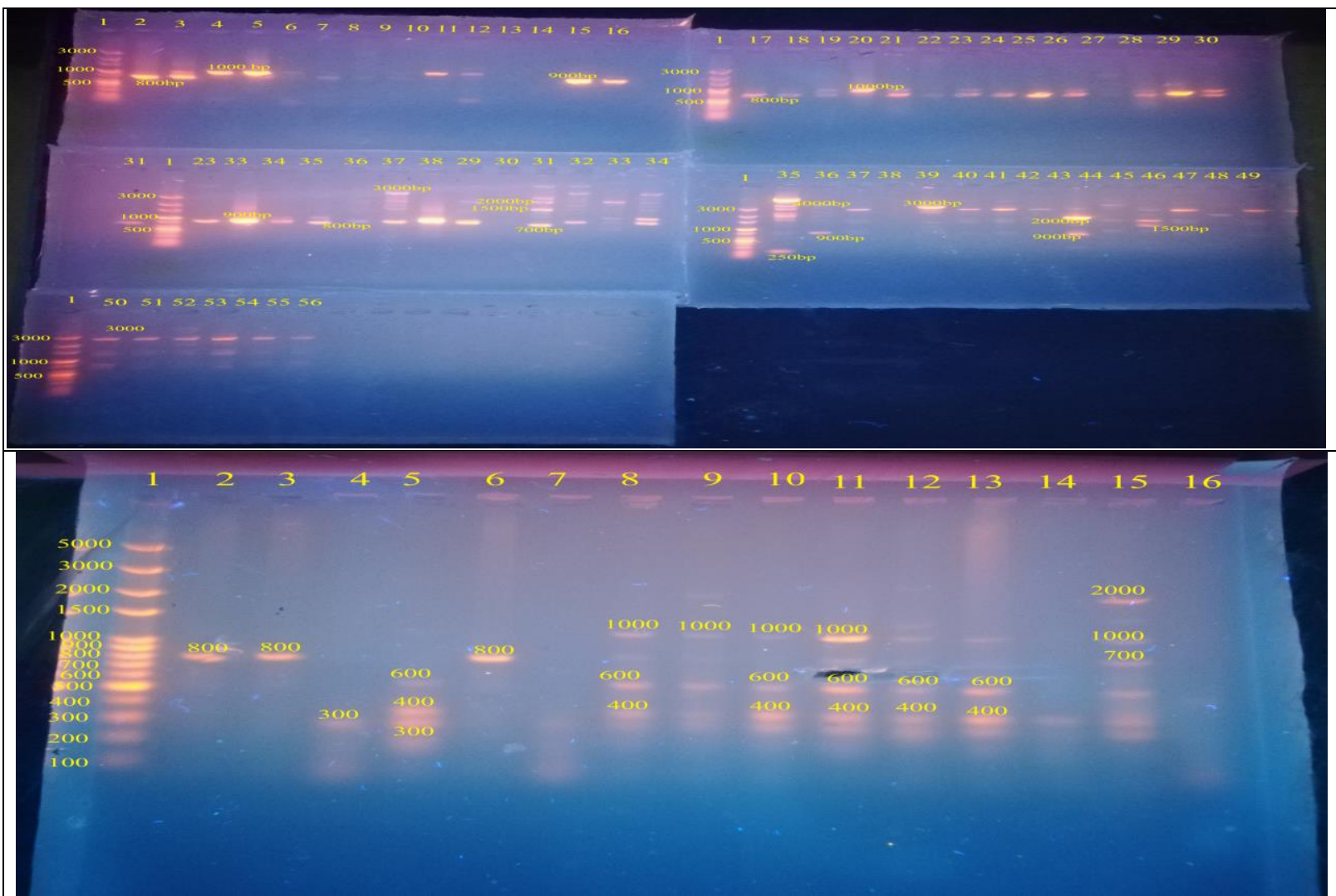

Fig. (1): Coagulase staphylococcus confirmed with coa gene primer, lane (1) ladder $100 \mathrm{bp}$ plus, lane (16) negative control, positive isolates with polymorphic bands, lanes (2, 3, 6 at $800 \mathrm{bp})(4,5$ at $300 \mathrm{bp})(5,12,13$ at 400,600 bp) (8:11 at 400, 600, $1000 \mathrm{bp})(15$ at700, 1000, $2000 \mathrm{bp}$ ) positive): coagulase staphylococcus, negative isolates $(7,14)$.

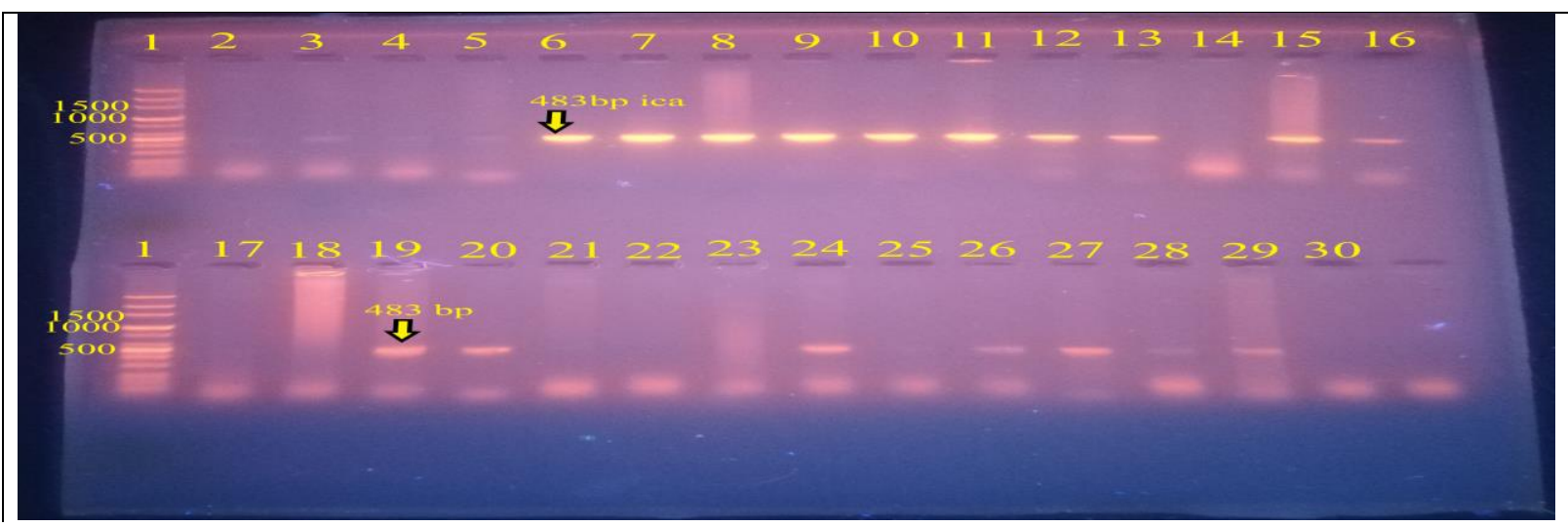

Fig. (2): Biofilm formation staphylococcus confirmed with ica gene primer at $483 \mathrm{bp}$, lane (1) ladder 100 bp plus, lane (29) control positive, lane (30) negative control, lanes (3:5, 26, 28 faint band, $6: 13,15,16,19,20,24,27$ at $483 \mathrm{bp}$ ) positive results.

Comparison between phenotypic staphylococcus on different phenotypic test and genotypic expression of staphylococcus by different genes, as random selection of 157 isolates positive golden yellow mannitol fermentation on MSA media showing with 16S universal staphylococcus gene 141/157 isolates surly staphylococcus, summarized biochemical tests resulted in 81/141 isolates typical phenotypic $S$. aureus in the other hand the nuc gene that proved as gene expression to typical $S$. aureus resulted in $111 / 141$ isolates were surely typical $S$. aureus, tube coagulase test resulted in $81 / 141$ isolates, while coa gene expressed in $130 / 141$ isolates this may returned to biofilm formation detected in 81/141 of examined isolates by ica gene. 
Table 5: Comparison between phenotypic staphylococcus on different phenotypic test and genotypic expression of staphylococcus by different genes.

\begin{tabular}{cccc}
\hline \multicolumn{2}{c}{ Phenotypic tests } & \multicolumn{2}{c}{ Genotypic expression } \\
\hline Microbial test & positive & Gene expression & positive \\
\hline MSA & 157 & $\begin{array}{c}\text { 16S universal } \\
\text { staphylococcus } \\
\text { primer }\end{array}$ & $141 / 157$ \\
\hline $\begin{array}{c}\text { typical } S . \text { aureus } \\
\text { depending on } \\
\text { biochemical tests }\end{array}$ & $81 / 141$ & nuc gene & $111 / 141$ \\
\cline { 3 - 4 } & & coa gene & $130 / 141$ \\
\hline
\end{tabular}

Genotypically coa gene was represented by polymorphism bands, as $50.8 \%$ (66/130) of positive coa gene represented by single band at $(700,800,900,1000,1500,3000 \mathrm{bp})$, $36.2 \%$ (47/130) had double bands (mainly at $700 / 1000 \mathrm{bp}), 10.7 \%(14 / 130)$ had three bands (mainly at $800 / 1500 / 3000 \mathrm{bp}$ ) and $2.3 \%(3 / 130)$ had four bands. Also classified into 52/66 of positive coa gene carried single bands, 45/47 of positive coa gene isolates carried double band, 13/14 of positive coa gene carried triple bands and only one isolates of positive coa gene isolates carried quarter band classified as $S$. aureus this was referred that most $S$. aureus isolated from milk sample carried mainly one to three fragments to coa gene

Table 6: Coa gene represented by polymorphism bands.

\begin{tabular}{|c|c|c|c|c|c|c|}
\hline $\begin{array}{l}\text { Single } c o a \\
\text { gene band }\end{array}$ & & $\begin{array}{l}\text { Double coa } \\
\text { gene bands }\end{array}$ & & $\begin{array}{c}\text { triple coa gene } \\
\text { bands }\end{array}$ & & $\begin{array}{c}\text { quarter coa gene } \\
\text { bands }\end{array}$ \\
\hline \multirow{2}{*}{700} & \multirow{2}{*}{20} & $200 / 5000$ & 1 & \multirow{2}{*}{$200 / 700 / 1000$} & \multirow{2}{*}{1} & \multirow{2}{*}{$600 / 800 / 900 / 1500$} \\
\hline & & $300 / 800$ & 1 & & & \\
\hline \multirow{2}{*}{800} & \multirow{2}{*}{27} & $700 / 800$ & 1 & \multirow{2}{*}{$600 / 900 / 1500$} & \multirow{2}{*}{2} & \multirow{2}{*}{$600 / 1500 / 2000 / 3000 \quad 1$} \\
\hline & & $700 / 1000$ & 19 & & & \\
\hline \multirow{2}{*}{900} & \multirow{2}{*}{10} & $700 / 2000$ & 1 & \multirow{2}{*}{$700 / 1000 / 1300$} & \multirow{2}{*}{1} & \multirow{2}{*}{$700 / 1000 / 1500 / 3000 \quad 1$} \\
\hline & & $700 / 3000$ & 4 & & & \\
\hline \multirow{2}{*}{1000} & \multirow{2}{*}{7} & $700 / 4000$ & 1 & \multirow{2}{*}{$700 / 1000 / 2000$} & \multirow{2}{*}{1} & \\
\hline & & $800 / 900$ & 3 & & & \\
\hline \multirow{2}{*}{1500} & \multirow{2}{*}{1} & $800 / 1500$ & 4 & \multirow{2}{*}{$700 / 1000 / 3000$} & \multirow{2}{*}{1} & \\
\hline & & $800 / 2000$ & 1 & & & \\
\hline \multirow{5}{*}{3000} & 1 & $800 / 3000$ & 2 & \multirow{2}{*}{$800 / 1000 / 1200$} & \multirow{2}{*}{1} & \\
\hline & 1 & $900 / 1000$ & 1 & & & \\
\hline & & $900 / 1500$ & 5 & \multirow{2}{*}{$800 / 1500 / 3000$} & \multirow{2}{*}{6} & \\
\hline & & $900 / 4000$ & 2 & & & \\
\hline & & $1000 / 1200$ & 1 & $900 / 1000 / 1500$ & 1 & \\
\hline \multirow{2}{*}{\multicolumn{2}{|c|}{$\begin{array}{c}66(50.8 \%) \\
52 \text { of them } S . \\
\text { aureus }\end{array}$}} & \multirow{2}{*}{\multicolumn{2}{|c|}{$\begin{array}{c}47(36.2 \%) \\
45 \text { of them S. aureus }\end{array}$}} & \multirow{2}{*}{\multicolumn{2}{|c|}{$\begin{array}{c}14(10.7 \%) \\
13 \text { of them } S . \text { aureus }\end{array}$}} & \multirow{2}{*}{$\begin{array}{c}3(2.3 \%) \\
\text { One of them S. aureus }\end{array}$} \\
\hline & & & & & & \\
\hline \multicolumn{7}{|c|}{$130(92.2 \%)$ positive coa gene } \\
\hline
\end{tabular}




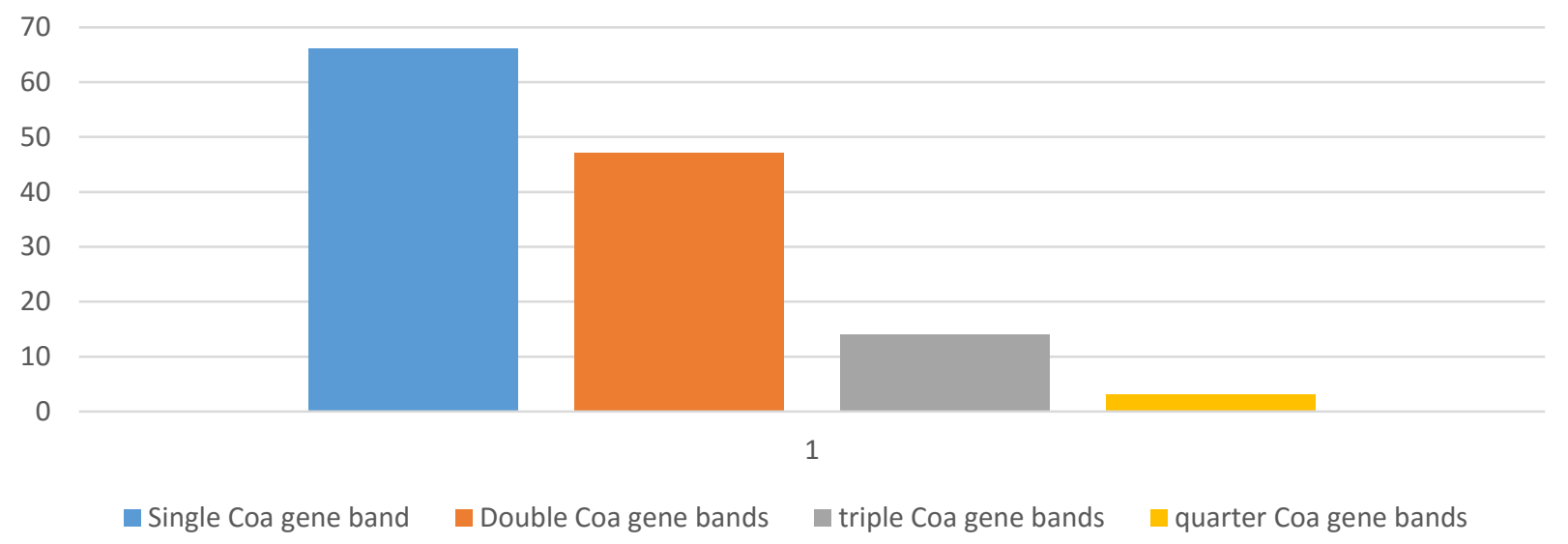

Chart (2): illustrated coa gene represented by polymorphism bands

S. aureus is one of the most important causes of nosocomial infections, (Kasper et al., 2005). Carlton et al., 2010 and Van der MeeMarquet et al., 2014) Although their reports have highlighted the increasing importance of CoNS species as opportunistic pathogens, but still $S$. aureus remains a major diseasecausing agent in veterinary medicine. Furthermore, the increasing role of animals as sources of methicillin-resistant $S$. aureus (MRSA), potentially pathogenic to humans, reinforces the importance of accurately identifying $S$. aureus. (Diederen and Kluytmans, 2006), The increasing rate of CA-MRSA infections in many areas, revealed unique pattern of virulence, clinical picture, and antimicrobial resistance, has important effects on treatment and infection control measures and has a serious challenge for the clinician.

our study detection was classified isolates firstly according to Procop et al. (2017) and Effendi et al. (2019) as classifying isolates in Table (2,3), which classified staphylococcus 271 isolates that cultured on MSA media as $240(88.6 \%)$ represented by yellow to orange colonies surround by yellow halo indicate $S$. aureus, $S$. intermidius, S. xylosus, S. haemolyticus, $S$. saprophyticus., $\quad S . \quad$ schleiferi subsp coagulans, S. delphini, on the other hand $31(11.4 \%)$ appear as pink colony without changing surround medium $S$. epidermidis, S. lugdunensis, S. hyicus, also classify by coagulase test tube 114/271(42\%) CoPS species isolates were $S$. aureus (81/114), $S$. intermedius, S. pseudintermedius, S. hyicus, S. schleiferi subsp coagulans, S. delphini, that similler to result of (Carrillo-Casas \& Miranda-Morales, 2012; Vanderhaeghen et al., 2015; USP, 1995; Sartori et al., 2018; Wald et al., 2019). Also isolates directed to biochemical test as Horstmann et al. (2012) record that differentiation of MRSP (methicillin- resistant $S$. pseudintermedius) from MRSA on MSA media were more complicated because of similar colony color and size as needed more biochemical test to differentiated them. And also identification and subtyping of such strains is very important to apply suitable infection control programs to control MRSA spread (Zecconi and Piccinini, 1999). Both phenotyping and genotyping can be used to identify MRSA, Felten et al. (2002) so gene typing identification has significant role and comparing between Table (3) and table (4) as summarized in Table (5) illustrated that $16 \mathrm{~S}$ primer resulted in $89.8 \%$ sure positive staphylococcus of suspected positive phenotypic staphylococcus isolates on MSA media and $10.2 \%$ sure negative staphylococcus (false positive on MSA media), our results refereed to sensitivity of MSA media 89.8\%) and this nearly matching sensitivity result of Kateete et al. (2010) on MSA media and lower result of Pumipuntu et al. (2017) with difference comparing items (molecular detection method with MSA culturing method). The difference in the results of molecular method 
still consider more accurate than MSA media as studies of Koskinen et al. (2009); Taponen et al. (2009); Elsayed et al. (2015); Hoque et al. (2018) and Ameen et al. (2019). This may returned to biofilm bacteria production that detection in $57.4 \%$, as Devriese et al. (1985) and Langlois et al. (1990) mentioned that Routine bacteriological tests used in the identification of $S$. aureus, like mannitol fermentation, DNAse production, VP, etc., are not enough for definitive characterization, also, Mathews et al. (1997), pay attention to the risk of possible diagnostic errors in the identification and differentiation of coagulase-negative $S$. aureus through conventional phenotypic assays. by using arbitrary primers to amplify target genes by PCR, and opinion of Mahmoudi et al. (2017) that referred to genotypic variation among different $S$ .aureus isolates, which may be considered as an important criterion when treating staphylococcal infection.

Our results detection in table $(3,4)$ nuc gene in $78.7 \%$ and coa gene in $92.2 \%$ of isolates this result agree with Saraiva et al. (2018) in their result targeting nuc genes $78 \%$, but our result with coa gene higher than result of their coa as $47 \%$, but our coa gene result agree with Abdulghany and Khairy, (2014) reported that about $93 \%$ of isolates carried typability of coa gene amplification, Da Silva and Da Silva, (2005) reported that about $97 \%$ of isolates carried typability of coa gene amplification.

Madison and Baselski, (1983); Brakstad et al. (1992), Sasaki et al. (2010) confirmed that the nuc gene has been specific to all $S$. aureus. But also Giannouli et al. (2010) mentioned that most of isolates of $S$. aureus has nuc gene, but some isolates were not positive for the gene, as they were suggesting that return to misidentification by PCR could be related to deletions or mutations occurring in the gene, but their recorded also coagulase production is regulated by coa gene in $S$. aureus. Saraiva, et al. (2018) mentioned that nuc gene and fem gene considered an accurate method to identify $S$. aureus species from animal sources.

Also result recorded in table $(2,3)$ : coa gene detected in $92.2 \%$, while tube coagulase test detected only in $57.4 \%$, which considered by Pourshadi and Klaas, (1984), Bannerman, (2003) a golden standard detection method, but Tiwari et al. (2008), Karahan et al. (2009) and Hamza et al. (2015) were disagreed them and proved in their study that the coagulase (coa) gene PCR the gold standard for the identification of $S$. aureus, Da Motta, (2014) and Zapotoczna et al., (2015), referred to that coagulase has an essential role in Staphylococcus, by using coa gene detection, with a high frequency of coa gene in bovine $S$. aureus. and Davis et al. (1990), Although the coagulase tube test is the standard phenotypic routine test used to identify $S$. aureus in biological samples, but also Goh et al. (1992), Aarestrup et al. (1995), Kapur et al. (1995), several groups have implemented the molecular analysis of the coagulase gene as an accurate defined test. Moreillon et al. (1995) this gene is associated with the capacity of the pathogen to coagulate fibrin and therefore plays a key role in the pathogenesis of the agent by conferring protection against host immune defense mechanisms and in biofilm production. Uses Coa gene primer as coagulase gene typing has proven to be a simple and effective means to identify coagulase-positive $S$. aureus isolates from both human and animal sources, Nada. et al. (1996). S. aureus isolated Classification based on the coa gene which has been considered a simple and accurate method for molecular typing (Da Silva and Da Silva, 2005). Schlegelova et al. (2003), all strains of $S$. aureus secrete coagulase enzyme, as a critical virulent factor.

The difference in our result between tube coagulase test and coa gene detection by PCR may agree with Bennett and Monday, 2003, that mentioned that tube coagulase test for $S$. intermedius and S. hyicus not detected by human plasma and that distinguish as 
clumping factor present in $S$. aureus cell binding to fibrinogen or fibrin present in human and rabbit. Also may return to Abdulghany and Khairy, 2014 observation the difference between biochemical test as MRCoNS isolates and 4 isolates, identified as Coagulase positive by coagulase test, were found to be negative with PCR, so molecular detection of $S$. aureus strains is very important and more accurate.

Also this may return to Coagulase is an enzyme produced by $S$. aureus that causes clotting of blood in the human host. $S$. aureus secretes two forms of coagulase enzyme, bound coagulase and free coagulase, Woodford and Sundsfjord, (2005) Friedman and Ratard, (2007), Free coagulase binds with coagulase-reacting factor (CRF) in plasma and creates a complex, staphylothrombin, Hosseinpour et al. (1992), Schroder et al. (2006).

The disagree between result of tube coagulase test and coa gene molecular detection by PCR may return to many comments, beginning from accuracy of tube coagulase test as Cowan and Steel, (1974) that a proved that the rabbit plasma was accepted in a tube coagulase test as an affirmation of the identification of staphylococcus aureus, as it was common to use human plasma broth in the bench, with tube testing and slide clumping factor, these with most human strains there is no difficulty, but were deficient in clumping factor and even in free Protein with strains of S. aureus, which are resistant to methicillin, according to Lally and Woolfrey, (1984), and Marples and Cooke, (1985). Also Sperber and Tatini (1974): reported that human plasma or a mixture of it and rabbit coagulase plasma EDTA is more suitable for use in the coagulase test than rabbit coagulase plasma EDTA alone. also, Sperber and Tatini, (1975) proved that a mixture of pig and rabbit plasma in the tube coagulase test is the best choice. Followed by Dickson and Marples, (1986) that proved the human plasma is better than rabbit plasma for human $S$. aureus strains, but rabbit plasma is necessary for animal strains. Also interpretive that epidemic methicillin resistant $S$. aureus, other resistant $S$. aureus and other $S$. aureus gave consistently strong positive results with the tube test, on the other hand recording that reference strains, not all true $S$. aureus were positive results in the tube test found. Also with Aarestrup et al. (1995); Su et al. (1999), as they were interpretive the variation is relevant to the bacterial pool, hard management, and environmental conditions in each geographical region.

But another opinion taken in consideration as reported with Silva et al. (2000): proved that their result of tube coagulase test for classifying Staphylococci could change as all $S$. aureus strains were coagulant positive but intensity of the test varied according to the source: environmental $S$. aureus strains gave $3+$ to $4+$, while of milk $S$. aureus strains isolated gave only $1+$ to $2+$ score. Also proved that $2.2 \%$ of $S$. aureus strains were thermo-nuclease negative and Sixteen thermo-nuclease positive and coagulase positive strains were identified as $S$. hyicus, and misdiagnosis may also taken by Karahan and Cetinkaya, (2007), in Turkey, from phenotypic 200 strains of $S$. aureus isolated from 700 milk samples of cows bovine mastitis milk samples, only 16 positive samples contained coa gene.

In our study, $92.2 \%$ of phenotypic Staphylococcus isolates had coa gene genotypically as recorded polymorphism model of the coa gene, as individual bands measuring 200 to $5000 \mathrm{bp}$ fragments, These results indicate a considerable heterogeneity in the coa gene of the isolated strains as in Table (6) Genotypically coa gene represented by polymorphism fragment, as $50.8 \%(66 / 130)$ of positive coa gene represented by single band at $(700,800,900$, 1000, 1500, $3000 \mathrm{bp}), 36.2 \%$ (47/130) had double bands (mainly at 700/1000 bp), $10.7 \%(14 / 130)$ had three bands (mainly at $800 / 1500 / 3000 \mathrm{bp})$ and $2.3 \%$ (3/130) had four bands. As classified into 52/66 of positive Coa gene carried single bands, 
45/47 of positive Coa gene isolates carried double band, 13/14 of positive coa gene carried triple bands and only one isolates of positive coa gene isolates carried quarter band classified as $S$. aureus, and this somewhat, agreement with results of Karahan and Cetinkaya, (2009) which found that their most isolates $(83.9 \%)$ produced a single band for coa after PCR amplification, with sizes of 500 to $1,400 \mathrm{bp}$, whereas a small number of isolates $(16.1 \%)$ yielded two amplification products. as higher than those shown in the study of Momtaz et al. (2011), only $27.9 \%$ of phenotypic $S$. aureus had coa gene genotypically. $73.8 \%$ of them contain $970 \mathrm{bp}$ fragment and $26.1 \%$ contain 730 bp fragments revalent to coa gene. Saei, et al. (2009), recorded S. aureus strains isolated from bovine mastitis milk samples reported 490 to 850 bp fragment. And also observed (Goh et al., 1992; Da Silva and Da Silva, 2005 in Brazil and Aslantas et al., 2007) and agreement also with those of Kursat, et al., (2011) that observed in a number of isolates their coa gene resulted insize polymorphisms (four to eight repeats) beside some of isolates showing a single amplicon. also Katsuda, et al. (2005), reported observation of three to nine tandem repeats in the coa gene; five tandem repeats was the most common form in bovine $S$. aureus strains. Also agree with Goh et al. (1992), that mentioned DNA sequence analysis of the Coagulase (coa) gene revealed heterogeneity region. PCR amplification of this region showed DNA bands of different size and number and we come out of all these results and observations and understand that most $S$. aureus have single, double, triple and quarter fragment /bands.

The coa gene, coding for the coagulase enzyme, can be used for DNA-based diagnosis of S. aureus. The coa gene is highly polymorphic because of differences in the sequence of the 30 variable region. Analysis of the coa gene in a variety of staphylococcal species has shown diversity in the amino acid sequence and the number of tandem repeats at the 30 end. There is heterogeneity in this domain, including the number of 81-bp tandem short sequence repeats encoding repeated 27 amino acid sequences in the $\mathrm{C}$-terminal region. Detecting the coagulase enzyme in staphylococci infections is important because it is considered as one of the pathogenic factors of this bacterium (Goh $e t$ al., 1992, Talebi-Satlou et al., 2012), and also we can consider the inaccuracy of result of the tube coagulase test return to geographical differences as Smole et al., 1998, proved that geographical differences can correlate with antigenic variation of capsular polysaccharides and surface glycol polysaccharides of $S$. aureus and can affect the identification test for $S$. aureus, a study has been carried out in three different centers in three European countries. Pérez-Roth et al. (2001) referred to the low frequency of this gene might be associated with Polymorphisms of the coa gene have been reported in $S$. aureus from different sources and animal species.

Vieira-da-Motta et al. (2001), Previous molecular population genetic analysis of $S$. aureus strains recovered from cows showed an alarming heterogeneity of circulating strains, even within a given herd or hospital. Regardless a phenotypic association, we believe that the heterogeneity observed for the coa gene has a potential discriminatory power for future epidemiological studies of veterinary and medical importance.

Sajadi et al. (2017): mentioned that their result of molecular coagulase-positive samples with polymorphic sizes reports emphasized that samples were $100 \%$ resistant to penicillin and higher resistance towards most antibiotics. Talebi-Satlou et al. (2012): proved that Coagulase-positive samples showed more resistance to antibiotics, which confirms the virulence of $S$. aureus.

The polymorphic bands to Coa gene may return to Coagulase gene has variance of amplicon which is in line with the reports of (Hookey et al., 1998, Talebi-Satlou et al., 2012, Afrough et al., 2013, Osmonov et al., 
2013, Sajadi S.N. et al., 2017). As Goh et al. (1992), Schwarzkopf and Karch, 1994, Da Silva and Da Silva, 2005 mentioned that previously, coa gene amplification was reported to produce single-banded PCR products in $S$. aureus strains isolated from human and animal samples, but thier studies notcied double-branded products for coa gene, but this was a rare finding. After that, Tiwari et al. (2008) recorded double and triple bands from human samples were observed. Gharib et al. (2013) reported Triple bands in Egypt from human and animal samples.

Abdulghany and Khairy, 2014 reported a completely different finding: multiple bands amplification products $(1,2,3,4,5$, and eight bands) were detected for Coa gene which classifying studied strains as $15 \mathrm{coa}$ PCR types, and this agreed partly with da Silva R. E. and da Silva N., 2005 (27 types), and disagreed with the most of other researchers: Janwithayanuchit et al. (2006), who determined 4 different patterns of coa gene in 129 MRSA isolates, Himabindu et al. (2009), who reported 3 classes among 85 isolates, Demir et al. (2011), who reported 4 patterns in 120 isolates, and Talebi-Satlou et al. (2012), who reported 4 products in 26 isolates as Goh et al. (1992), suggest That most studies that the variability in size and number of coa bands detected may be due to the presence of different allelic coa gene forms in MRSA, allowing one strain to form multiple amplicons.

Also, coa gene polymorphism result in some studies Attributed to Kav et al. (2011) that suggested that milking personnel may play a role in the transmission of S. aureus, and coa restriction fragment length polymorphism.

S. aureus has the ability to produce biofilm to facilitate them to withstand the host immune response recognized as one factor contributing to chronic or persistent infections, represented by biosynthesis of polysaccharide intercellular adhesion (PIA) molecules, Different studies have shown the decisive role of the ica gene as virulence factors in staphylococcal infections Namvar, et al. (2013). As ica gene detected in the study represented in $81(57.4 \%)$. As (Kostaki et al., 2012; Mah 2012; Bridier et al., 2015 and Avila-Novoa et al., 2018) proven that most of the $S$. aureus strains formed the biofilm in an ica-dependent mechanism as 74 biofilm-positive strains, including about $76 \%$ were ica. As biofilms, increase bacterial resistance to environmental stresses (including cleaning, disinfection and inhibition) enabling these microorganisms to persist on surfaces and processing equipment, compared to planktonic cells. Namvar et al. (2013), proven that the ica-encoded gene (biofilm) one of virulence factors produced by staphylococcus that facilitates them to withstand the host immune response and is recognized as one factor contributing to chronic or persistent infections.

\section{CONCOLUSION}

The nuc gene still considered as the main golden diagnostic slandered technique in identification $S$. aureus as quickly and accurate tool than the MSA media and and the coa gene more accurate in the face of the tube coagulase test which became old tools in detection coagulase virulent gene due to fast developing of mutation by $S$. aureus to protect themselves from most antibiotic forming biofilm (ica gene) surrounding them (which protected staphylococcus from phagocytosis by immune cells and persist infection due to resistance to environmental stresses (including cleaning, disinfection and inhibition mechanism).

\section{REFERANCES}

Aarestrup, F.M.; Dangler, C.A. and Sordillo L.M. (1995): Prevalence of coagulase gene polymorphism in Staphylococcus aureus isolates causing bovine mastitis. Canadian Journal of Veterinary Research, 59(2), 124.

Abbas, B.A.; Khudor, M.H. and Hanoon, B.M. (2014): Isolation and identification of Staphylococcus aureus from bovine and 
the detection of its coagulase gene (coa) using polymerase chain reaction (PCR). Sci. Res. Essays, 9(20): 864-868.

Abdulghany, H.M. and Khairy, R.M. (2014): The frequency of methicillin-resistant Staphylococcus aureus and coagulase gene polymorphism in Egypt. International journal of bacteriology, 2014., Article ID 680983, 6 pages http://dx.doi.org/ 10.1155/ 2014/680983

Afrough, P.; Pourmand, M.R.; Sarajian, A.A.; Saki, M. and Saremy, S. (2013): Molecular investigation of staphylococcus aureus, Coa and spa genes in ahvaz city hospitals staff nose compared with patients clinical samples. Jundishapur J Microbiol. 2013; 6(4): 5377.

Altschul, S.F.; Gish, W.; Miller, W.; Myers, E.W. and Lipman, D.J. (1990): Basic local alignment search tool. Journal of molecular biology, 215(3), 403-410.

Ameen, F.; Reda, S.A.; El Shatoury, S.; Riad, E.M.; Enany, M.E. and Alarfaj, A.A. (2019): $\quad$ Prevalence of antibiotic resistant mastitis pathogens in dairy cows in Egypt and potential biological control agents produced from plant endophytic actinobacteria. Saudi J. Biol. Sci. 2019, 26, 1492-1498.

American Public Health Association, (APHA) (1966): Recommended Methods for the Microbiological Examination of Foods, 2nd Ed. APHA Inc., New York.

Anonymous (1990): Microbiological Products for the Diagnosis of Bovine Udder Infection. 3rd Ed., National Mastitis Council, Avlington, Virginia, USA.

APHA (1992): Standard Methods for Water and Waste water Examination. 17th edn, American Public Health Association, Washington, DC.

Aslantas, O.; Demir, C.; Turutoglu, H.; Cantekin, Z.; Ergun, Y. and Dogruer, G. (2007): Cagulase gene polymorphism of Staphylococcus aureus isolated form subclinical mastitis. Turk J Vet Anim Sci 31:253-257, http://journals.tubitak. gov.tr/ veterinary/issues/vet-07-31-4/ vet-31-4-7-0609-8.pdf

Avila-Novoa, M.G.; Iñíguez-Moreno, M.; Solís-Velázquez, O.A.; González-Gómez,
J.P.; Guerrero-Medina, P.J. and Gutiérrez-Lomelí, M. (2018): Biofilm formation by Staphylococcus aureus isolated from food contact surfaces in the dairy industry of Jalisco, Mexico. Journal of Food Quality, 2018. Article ID 1746139, 8 pages. https://doi.org/10.1155/2018/1746139.

Bannerman, T.L. (2003): Staphylococcus, micrococcus, and other catalase-positive cocci that grow aerobically. In Manual of Clinical Microbiology, pp. 384-404. Edited by Murray, P.R., Baron, E.J., Jorgensen, J.H., Pfaller, M.A., Yolken, R. H. and Washington, D.C., (2003): American Society for Microbiology 2003.

Bennett, R.W. and Monday, S.R. (2003): international handbook of foodborne pathogen, chapter (4) p 41:63,

Brakstad, O.G.; Aasbakk, K. and Maeland, J.A. (1992): Detection of Staphylococcus aureus by polymerase chain reaction amplification of the nuc gene. Journal of clinical microbiology, 30(7), 1654-1660.

Bridier, A.; Sanchez-Vizuete, P.; Guilbaud, M.; Piard, J.C.; Naitali, M. and Briandet, R. (2015): Biofilm-associated persistence of food-borne pathogens. Food microbiology, 45, 167-178.

Carlton, L.G.; John, F.; Glenn, J.S. and Charles, O.T. (2010): Pathogenesis of bacterial infections in animals. 4th ed. "Staphylococcus", P: 75-90.

Carrillo-Casas, E.M. and Miranda-Morales, R.E. (2012): Bovine mastitis pathogens: prevalence and effects on somatic cell count. In Milk Production-An Up-toDate Overview of Animal Nutrition, Management and Health. Intech Open.

Carter, G.R. and Cole, J.R. (1990): Diagnostic procedures in veterinary bacteriology and mycology. 5th edn., Academic Press, Inc., PP: 469-478.

Collee, J.G.; Duguid, J.P.; Fraser, A.G. and Marmion, B.P. (1989): Mackie and McCartney Practical Medical Microbiology, Vol. 2, 13th Ed., Churchill Livingston, London, UK.

Cowan, S.T. and Steel, K.G. (1974): Manual for the identification of medical bacteria. 
2nd ed. Cambridge: Cambridge University Press, 1974.

Cruickshank, $\quad R . \quad$ (1975): Medical Microbiology: Volume 2: The Practice of Medical Microbiology. Churchill Livingstone.

Da Motta, C.C. (2014): Verification of molecular characterization of coagulase positive Staphylococcus from bovine mastitis with matrix-assisted laser desorption ionization, time-of-flight mass spectrometry (MALDI-TOF MS) mass spectrometry. Afr J Microbiol Res 2014; 8: 3861-3866.

Da Silva, R.E. and Da Silva, N. (2005): Coagulase gene typing of Staphylococcus aureus isolated from cows with mastitis in southeastern Brazil. Canadian journal of veterinary research, 69(4), 260.

Davis, B.D.; Dulbecco, R.; Eisen, H.N. and Ginsberg, H.S. (1990): Staphylococci. In: Novick, R.P. (ed.), Microbiology. J.B. Lippincott Co., Phyladelphia, 1990, p.539-550.

Demir, C.; Aslantaş, Ö.; Duran, N.; Ocak, S.

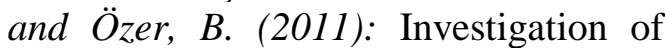
toxin genes in Staphylococcus aureus strains isolated in Mustafa Kemal University Hospital. Turkish Journal of Medical Sciences, 41(2), 343-352.

Devriese, L.A.; Schleifer, K.H. and Adegoke, G.O. (1985): Identification of coagulase- negative staphylococci from farm animals. Journal of Applied Bacteriology, 58(1), 45-55.

Dickson, J.I. and Marples, R.R. (1986): Coagulase production by strains of Staphylococcus aureus of differing resistance characters: a comparison of two traditional methods with a latex agglutination system detecting both clumping factor and protein A. Journal of clinical pathology, 39(4), 371-375.

Diederen, B.M.W. and Kluytmans, J.A.J.W. (2006): The emergence of infections with community-associated methicillin resistant Staphylococcus aureus. Journal of Infection, 52(3), 157-168.

Effendi, M.H.; Hisyam, M.A.M.; Hastutiek, P. and Tyasningsih, W. (2019): Detection of coagulase gene in Staphylococcus aureus from several dairy farms in East
Java, Indonesia, by polymerase chain reaction, Veterinary World, 12(1): 6871. doi: $10.14202 /$ vetworld. 2019.68-71

Elsayed, M.S.; Abd Elrahman Mahmoud ElBagoury, M. and Dawoud, A. (2015): Phenotypic and genotypic detection of virulence factors of Staphylococcus aureus isolated from clinical and subclinical mastitis in cattle and water buffaloes from different farms of Sadat City in Egypt. Veterinary World, 8(9), 1051.

European Pharmacopoeia 10th Edition, (2020): 2. United States Pharmacopeia National Formulary 2018: USP 41 NF 36 3. Japanese Pharmacopeia 17th Edition (2017)

Felten, A.; Grandry, B.; Lagrange, P.H. and Casin, I. (2002): Evaluation of three techniques for detection of low-level methicillin-resistant Staphylococcus aureus (MRSA): a disk diffusion method with cefoxitin and moxalactam, the Vitek 2 system, and the MRSA-screen latex agglutination test. Journal of clinical microbiology, 40(8), 2766-2771.

Foster, T.J. and Geoghegan, J.A. (2015): Chapter 37: Staphylococcus aureus. In: Tang, Y.W., Sussman, M., Liu, D., Poxton, I. and Schwartzman, J., editors. Molecular Medical Microbiology. 2nd ed. Academic Press, Boston. p655-674.

Friedman, DA. and Ratard, RC. (2007): The Louisiana anti-biogram In vitro antibiotic sensitivity patterns 2003, 2004. Louisiana, Louisiana State University School of Public Health and Louisiana Department of Health: Louisiana State University School of Public Health and Louisiana Department of Health; 2007.

Gharib, A.; Attia, A. and Bendary, M. (2013): Detection of the coa gene in Staphylococcus aureus from different sources by polymerase chain reaction. Suez Canal Veterinary Medical Journal. SCVMJ, 18(1), 167-177.

Giannouli, S.; Labrou, M.; Kyritsis, A.; Ikonomidis, A.; Pournaras, S.; Stathopoulos, C. and Tsakris, A. (2010): Detection of mutations in the FemXAB protein family in oxacillin-susceptible mecA-positive Staphylococcus aureus 
clinical isolates. Journal of Antimicrobial Chemotherapy, 65(4), 626-633.

Goh, S.H.; Byrne, S.K.; Zhang, J.L. and Chow, A.W. (1992): Molecular typing of taphylococcus aureus on the basis of coagulase gene polymorphisms. Journal of Clinical Microbiology, 30(7), 16421645.

Hamza, D.A.; Dorgham, S.M. and Arafa, A. (2015): Coagulase gene typing with emphasis on methicillin resistance staphylococci, Emergence to public health. Adv Infect Dis. 2015; 05(4): 196-203.doi:10.4236/aid.2015.54025.

Himabindu, M.; Muthamilselvan, D.S.; Bishi, D.K. and Verma, R.S. (2009): Molecular analysis of coagulase gene polymorphism in clinical isolates of methicillin resistant Staphylococcus aureus by restriction fragment length polymorphism based genotyping. Am J Infect Dis, 5(2), 163-9.

Hookey, J.V.; Richardson, J.F.; Cookson, B.D. (1998): Molecular typing of Staphylococcus aureus based on PCR restriction fragment length polymorphism and DNA sequence analysis of the coagulase gene. J Clin Microbiol 36:1083-1089, PMID: 9542942.

Hoque, M.N.; Das, Z.C.; Rahman, A.N.M.A.; Haider, M.G. and Islam, M.A. (2018): Molecular characterization of Staphylococcus aureus strains in bovine mastitis milk in Bangladesh. International Journal of Veterinary Science and Medicine, 6(1), 53-60.

Hosseinpour, M.; Sabokbar, M.; Bakhtiyari, A. and Parsa, SH. (1992): Tracking comparative Salmonella in assembled isolate from Tehran with three methods, molecular, culture and ELISA. J microbial world. 1992; 1(14):62-72.

Janwithayanuchit, I.; Ngam-Ululert, S.; Paungmoung, P. and Rangsipanuratn, $W$. (2006): Epidemiologic study of methicillin-resistant Staphylococcus aureus by coagulase gene polymorphism. Science Asia, 32(32), 127-32.

Kapur, V.; Sischo, W.M.; Greer, R.S.; Whittam, T.S. and Musser, J.M. (1995):
Molecular population genetic analysis of Staphylococcus aureus recovered from cows. J. Clin. Microbiol., 33: 376-380, 1995.

Karahan, M. and Cetinkaya, B. (2007): Coagulase gen polymorphism detected by PCR in Staphylococcus aureus isolated form subclinical bovine mastitis in Turkey. Vet J 174:428-431. doi:10.1016/j.tvj1.2006.05.016

Karahan, M.; Acik, M.N. and Cetinkaya, B. (2009): Investigation of toxin genes by polymerase chain reaction in Staphylococcus aureus strains isolated from bovine mastitis in Turkey. Foodborne Pathog. Dis. 6:1029-1035.

Kasper, D.; Brunwald, E.; Fauci A. Hauser, S.; Longo, D. and Weinstein, R. (2005): Principles of Internal Medicine, 16ed., "Hospital acquired infections". 2005, P: 775-821

Kateete, D.P.; Kimani, C.N.; Katabazi, F.A.; Okeng, A.; Okee, M.S.; Nanteza, A. and Najjuka, F.C. (2010): Identification of Staphylococcus aureus: DNase and Mannitol salt agar improve the efficiency of the tube coagulase test. Annals of clinical microbiology and antimicrobials, 9(1), 1-7.

Katsuda, K.; Hata, E.; Kobayashi, H.; Kohmoto, M.; Kawashima, K.; Tsunemitsu, H. and Eguchi, M. (2005): Molecular typing of Staphylococcus aureus isolated from bovine mastitic milk on the basis of toxin genes and coagulase gene polymorphisms. Veterinary microbiology, 105(3-4), 301305.

Kav, K.; Col, R. and Ardic, M. (2011): Characterization of Staphylococcus aureus isolates from white-brined Urfa cheese. Journal of food protection, 74(11), 1788-1796.

Koskinen, M.T.; Holopainen, J.; Pyörälä, S.; Bredbacka, P.; Pitkälä, A.; Barkema, H.W. and Kelton, D. (2009): Analytical specificity and sensitivity of a real-time polymerase chain reaction assay for identification of bovine mastitis pathogens. Journal of Dairy Science, 92(3), 952-959.

Kostaki, M.; Chorianopoulos, N.; Braxou, E.; Nychas, G.J. and Giaouris, E. (2012): 
Differential biofilm formation and chemical disinfection resistance of sessile cells of Listeria monocytogenes strains under monospecies and dualspecies (with Salmonella enterica) conditions. Applied and environmental microbiology, 78(8), 2586-2595.

Lally, R. and Woolfrey, B. (1984): Clumping factor defective MRSA. Eur J Clin Microbiol 1984; 3: 151-2.

Langlois, B.E.; Parlindungan, A.K.; Harmon, R.J. and Akers, K. (1990): Biochemical Characteristics of Staphylococcus species of human and bovine origin. J. Food Prot. (JP., 1990), 53(2): 119-126, 1990.

Lundberg, A.; Nyman, A.; Unnerstad, H.E. and Waller, K.P. (2014): Prevalence of bacterial genotypes and outcome of bovine clinical mastitis due to Streptococcus dysgalactiae and Streptococcus uberis. Acta Vet. Scand., 56: 80. https://doi. org/10.1186/s13028014-0080-0

MacFaddin J.F. (1980): Biochemical tests for identification of medical bacteria. The Williams and Wilkins Company Balatmore, U.S.A.

Madison, B.M. and Baselski, V.S. (1983): Rapid identification of Staphylococcus aureus in blood cultures by thermonuclease testing. J Clin Microbiol 1983; 18: 722-724.

Mah, T.F. (2012): Biofilm-specific antibiotic resistance. Future microbiology, 7(9), 1061-1072.

Mahmoudi, H.; Arabestani, M.R.; Mousavi, S.F. and Alikhani, M.Y. (2016): Molecular analysis of the coagulase gene in clinical and nasal carrier isolates of methicillin-resistant Staphylococcus aureus by restriction fragment length polymorphism. .J. Glob. Antimicrobial. Resist. 2017; 8: 41-5.doi: 10.1016/ j.jgar.2016.10.007.[PubMed:27987442]

Marples, R.R. and Cooke, E.M. (1985): Report of a Workshop on methicillin- resistant Staphylococcus aureus. J Hosp Infect 1985; 6: 342-8.

Mathews, K.R.; Roberson, J.; Gillespie, B.E.; Luther, D.A. and Oliver, S.P. (1997): Identification and differentiation of coagulase-negative Staphylococcus aureus by Polymerase Chain Reaction. J. Food Prot. (JP., 2017), 60(6): 686-688, 1997

Momtaz, H.; Tajbakhsh, E.; Rahimi, E. and Momeni, M. (2011): Coagulase gene polymorphism of Staphylococcus aureus isolated from clinical and sub-clinical bovine mastitis in Isfahan and Chaharmahal va Bakhtiari provinces of Iran. Comparative clinical pathology, 20(5), 519-522.

Moreillon, P.; Entenza, J.M.; Francioli, P.; McDevitt, D.; Foster, T.J.; Francois, P. and Vaudaux, P. (1995): Role of Staphylococcus aureus coagulase and clumping factor in pathogenesis of experimental endocarditis. Infection and immunity, 63(12), 4738-4743.

Nada, T.; Ichiyama, S.; Osada, Y.; Ohta, M.; Shimokata, K.; Kato, N. and Nakashima, N. (1996): Comparison of DNA fingerprinting by PFGE and PCR-RFLP of the coagulase gene to distinguish MRSA isolates. J Hosp Infect 32: 305317, PMID: 8744515

Namvar, A.E.; Asghari, B.; Ezzatifar, F.; Azizi, G. and Lari, A.R. (2013): Detection of the intercellular adhesion gene cluster (ica) in clinical Staphylococcus aureus isolates. GMS hygiene and infection control, 8(1).

Osmonov, D.; Ozcan, K.S.; Erdinler, I.; Altay, S.; Yildirim, E. and Turkkan, C. (2013): Cardiac device related endocarditis, 31 Years experience. J Cardiol. 2013; 61(2): 175-80.doi: 10.1016/j.jjcc. 2012.08.019.

Paharik, A.E. and Horswill, A.R. (2016): The staphylococcal biofilm: adhesins, regulation, and host response. Virulence Mechanisms of Bacterial Pathogens, 529-566. https://doi. org/ 10.1128/ microbiolspec.VMBF-0022-2015 (2016).

Pérez-Roth, E.; Claverie-Martın, F.; Villar, J. and Mendez-Alvarez, S. (2001): Multiplex PCR for simultaneous identification ofstaphylococcus aureus and detection of methicillin and mupirocin resistance. Journal of clinical microbiology, 39(11), 4037-4041.

Pilla, R.; Snel, G.G.; Malvisi, M. and Piccinini, R. (2013): Duplex real-time 
PCR assay for rapid identification of Staphylococcus aureus isolates from dairy cow milk. Journal of dairy research, 80(2), 223-226.

Pourshadi, M. and Klaas, J. (1984): Evaluation of latex agglutination and microtube coagulase tests for detection of Staphylococcus aureus. Diagn Microbiol Infect Dis 1984; 2: 287-91.

Procop, G.W.; Church, D.L.; Hall, G.S.; Janda, W.M.; Koneman, E.W.; Schreckenberger, P.C. and Woods G.L. (2017): Koneman's Color Atlas and Textbook of Diagnostic Microbiology. Chapter 12 Gram-positive cocci part 1: streptococci and related gram positive cocci, P: 670-732.

Pumipuntu, N.; Kulpeanprasit, S.; Santajit, S.; Tunyong, $\quad W . ; \quad K o n g-n g o e n, \quad T . ;$ Hinthong, $W$. and Indrawattana, $N$. (2017): Screening method for Staphylococcus aureus identification in subclinical bovine mastitis from dairy farms. Veterinary world, 10(7), 721. Published online 2017 Jul 1. doi: 10.14202/vetworld.2017.721-726

Quinn, P.J.; Carter, M.E.; Markey, B.K. and Carter, G.R. (1994): Clinical Veterinary Microbiology. Mosby, London, 648 pp.

Saei, H.D.; Ahmadi, M.; Mardani, K. and Batavani, R.A. (2009): Molecular typing of Staphylococcus aureus isolated from bovine mastitis based on polymorphism of the coagulase gene in the north west of Iran. Vet Microbiol 137: 202-206, PMID: 19195799

Sajadi, S.N.; Kaboosi, H. and Ghadikolii F.P. (2017): Relationship between Antibiotic Resistance Patterns and Coagulase in Clinical Isolates of Staphylococcus aureus in Nowshahr and Chalous. Zahedan J Res Med Sci. 2017 November; 19(11):e55079. Published on line 2017 November 30. doi: 10.5812/zjrms.55079.

Saraiva, M.M.; De Leon, C.M.; Santos, S.C.; Stipp, D.T.; Souza, M.M.; Santos Filho, L. and Oliveira, C.J. (2018): Accuracy of PCR targeting different markers for Staphylococcus aureus identification: a comparative study using matrix-assisted laser desorption/ionization time-of-flight mass spectrometry as the gold standard. Journal of Veterinary Diagnostic Investigation, 30(2), 252255.

Sartori, C.; Perreten, V.; Ivanovic, I.; HärdiLanderer, M.C. and Graber, H.U. (2018): Lack of intramammary niche recolonization during a sanitation program for the contagious mastitis pathogen Staphylococcus aureus genotype B. Journal of dairy science, 101(9), 8296-8300.

Sasaki, T.; Tsubakishita, S.; Tanaka, Y.; Sakusabe, A.; Ohtsuka, M.; Hirotaki, S. and Hiramatsu, K. (2010.): MultiplexPCR method for species identification of coagulase-positive staphylococci. Journal of clinical microbiology, 48(3), 765-769.

Schlegelova, J.; Dendis, M.; Benedik, J.; Babak, V. and Ryšánek, D. (2003): Staphylococcus aureus isolates from dairy cows and humans on a farm differ in coagulase genotype. Veterinary Microbiology, 92(4), 327-334.

Schroder, A.; Schroder, B.; Roppenser, B.; Linder, S.; Sinha, B. and Fassler, R. (2006): $\quad$ Staphylococcus aureus fibronectin binding protein, a induces motile attachment sites and complex actin remodeling in living endothelial cells. Mol Biol Cell. 2006; 17(12): 5198-210.doi:10.1091/mbc.E06-050463.

Schwarzkopf, A. and Karch, H. (1994): Genetic variation in Staphylococcus aureus coagulase: potential and limits for use as epidemiological marker. $\mathrm{J}$ Clin Microbiol 32:2407-2412, PMID: 7814475

Shawky, N.M.A.; Eskander, D.K.; Wahba, A.K.A. and Mohamad, A.A. (2013): A biosecurity measures application with proper treatment to overcome the risk factors that limit effective control of subclinical mastitis in dairy buffalo farms-a field Study. Nat Sci, 11(7), 140151.

Silva, W.P.D.; Destro, M.T.; Landgraf, M. and Franco, B.D. (2000): Biochemical characteristics of typical and atypical Staphylococcus aureus in mastitic milk and environmental samples of Brazilian 
dairy farms. Brazilian Journal of Microbiology, 31(2), 103-106.

Smole, SC.; Aronson, E.; Durbin, A.; Brecher, SM. and Arbeit, RD. (1998): Sensitivity and specificity of an improved rapid latex agglutination test for identification of methicillin-sensitive and -resistant Staphylococcus aureus isolates. J Clin Microbiol 1998; 36: 1109-12.

Sperber, W.Z. and Tatini, S.R. (1975): Interpretation of the tube coagulase test for identification of Staphylococcus aureus. Applied microbiology, 29(4), 502-505 (Abstr. Annu. Meet. Am. Soc. Micro- biol. 1974, E67, p. 12)

Su, C.; Herbelin, C.; Frieze, N.; Skardova, O. and Sordillo, L.M. (1999): Coagulase gene polymorphism of Staphylococcus aureus isolates from dairy cattle in different geographical areas. Epidemiol Infect 122:329-336, PMID: 10355800

Talebi Satlou R.; Ahmadi, M. and Dastmalchi Saei, H. (2012): Restriction fragment length polymorphism genotyping of human staphylococcus aureus isolates from two hospitals in urmia region of iran using the Coa gene.Jundishapur J. Microbiol. 2012; 5(2): 416-20.doi: 10.5812/jjm. 3522 .

Taponen, S.; Salmikivi, L.; Simojoki, H.; Koskinen, M.T. and Pyörälä, S. (2009): Real-time polymerase chain reactionbased identification of bacteria in milk samples from bovine clinical mastitis with no growth in conventional culturing. Journal of dairy science, 92(6), 2610-2617.

Tiwari, H.K.; Sapkota, D. and Sen, M.R. (2008): Evaluation of different tests for detection of Staphylococcus aureus using coagulase (coa) gene PCR as the gold standard.

United States Pharmacopeia National Formulary (2018): USP 41 NF 363.

USPH (1995): The United States Pharmacopeia: USP 28: NF 23, 28th rev. of The Pharmacopeia of the U.S., 23rd ed. of The National Formulary; United States Pharmacopeial Convention; Rockville, MD, 2005; p 1110.

USPH (1995): The United States Pharmacopeia (23rd ed.). Rockville, MD: The United States Pharmacopeial
Convention. 1995. and Japanese Pharmacopeia 17th Edition (2017)

Van Der Haeghen, W.; Piepers, S.; Leroy, F.; Van Coillie, E.; Haesebrouck, F. and De Vliegher, S. (2015): Identification, typing, ecology and epidemiology of coagulase negative staphylococci associated with ruminants. The Veterinary Journal, 203(1), 44-51.

Van der Mee-Marquet, N.L.; Corvaglia, A.; Haenni, M.; Bertrand, X.; Franck, J.B.; Kluytmans, J. and François, P. (2014): Emergence of a novel subpopulation of CC398 Staphylococcus aureus infecting animals is a serious hazard for humans. Frontiers in Microbiology, 5, 652.

Vieira-da-Motta, O.; Folly, M.M. and Sakyiama, C.C.H. (2001): Detection of different Staphylococcus aureus strains in bovine milk from subclinical mastitis using PCR and routine techniques. Brazilian Journal of Microbiology, 32(1), 27-31.

Woodford, N. and Sundsfjord, A. (2005): Molecular detection of antibiotic resistance: when and where? J Antimicrob Chemother. 2005; 56(2): 259-61. doi: 10.1093/jac/dki195. [PubMed: 15967769].

Youssif, N.H.; Hafiz, N.M.; Halawa, M.A. and Saad, M.F. (2020): Influence of Some Hygienic Measures on the Prevalence of Subclinical Mastitis in a Dairy Farm. International Journal of Dairy Science, 15: 38-47. DOI: 10.3923/ ijds.2020.38.47

Zadoks, R.N.; Allore, H.G.; Barkema, H.W.; Sampimon, O.C.; Wellenberg, G.J.; Gröhn, Y.T. and Schukken, Y.H. (2001): Cow-and quarter-level risk factors for Streptococcus uberis and Staphylococcus aureus mastitis. Journal of Dairy Science, 84(12), 2649-2663.

Zapotoczna, M.; McCarthy, H.; Rudkin, J.K.; O'Gara, J.P. and O'Neill, E. (2015): An essential role for coagulase in Staphylococcus aureus biofilm development reveals new therapeutic possibilities for device-related infections. The Journal of infectious diseases, 212(12), 1883-1893. 
Zecconi, A. and Piccinini, R. (1999): "Teoria e pr'atica de controle de mastitepor Staphylococcus aureus," Napgama, vol.5, no.6, pp. 4-11, 1999.

Güler, L.; Ok, Ü.; Gündüz, K.; Gülcü, Y. and

Hadimli, H.H. (2005): Antimicrobial susceptibility and coagulase gene typing of Staphylococcus aureus isolated from bovine clinical mastitis cases in Turkey. Journal of dairy science, $88(9)$, 3149-3154.

\section{الاختلاف بين التوصيف الظاهرى والجينى للمكور العنقودى الأهبى المعزول من الابقار المصابة بالتهاب الضرع فى مصر المنود المر}

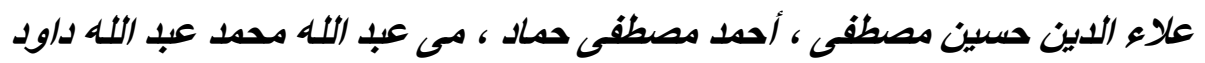

المكورات العنقودية الذهبية أحد أهم أسباب عدوي المستشفيات ، ومسببات الأمراض المعدية الرئيسية التي تلعب دورًا

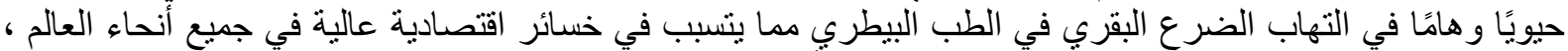

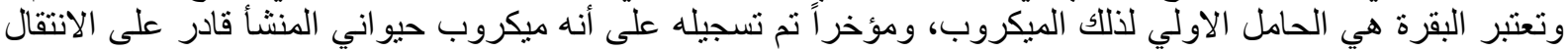

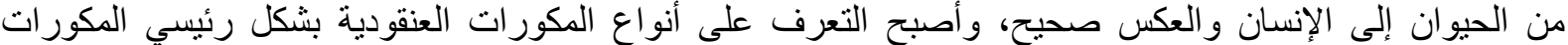

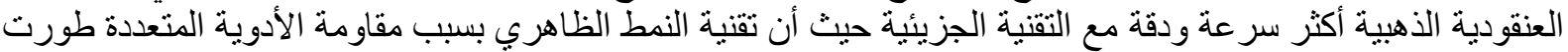

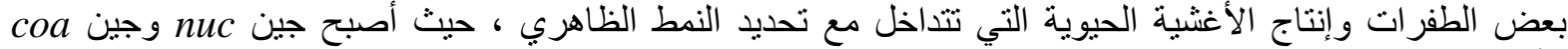

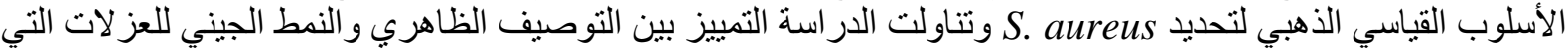

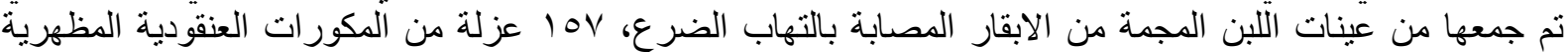

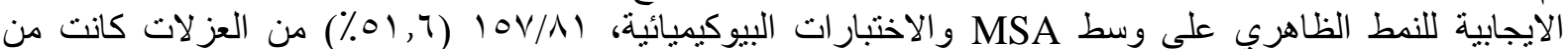

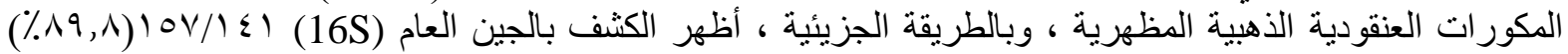

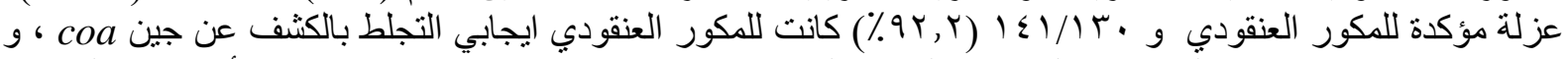

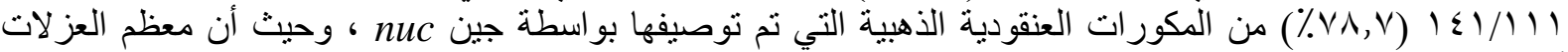

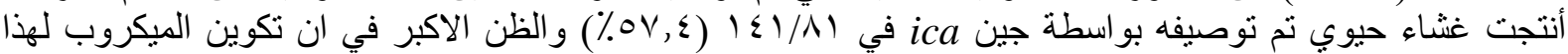
الغشاء حوله تسبب في تداخل النتايج للتوصيف الظاهري بو اسطة الاختبار ات البيوكيميائية. 